\title{
Interpersonal Relationships as Sources of Medical Student Stress
}

Beverly Jones, MD

Thomas Jefferson University

Follow this and additional works at: https://jdc.jefferson.edu/jeffjpsychiatry

Part of the Psychiatry Commons

Let us know how access to this document benefits you

\section{Recommended Citation}

Jones, MD, Beverly (1983) "Interpersonal Relationships as Sources of Medical Student Stress," Jefferson Journal of Psychiatry. Vol. 1 : Iss. 1 , Article 4.

DOI: https://doi.org/10.29046/JJP.001.1.003

Available at: https://jdc.jefferson.edu/jeffjpsychiatry/vol1/iss1/4

This Article is brought to you for free and open access by the Jefferson Digital Commons. The Jefferson Digital Commons is a service of Thomas Jefferson University's Center for Teaching and Learning (CTL). The Commons is a showcase for Jefferson books and journals, peer-reviewed scholarly publications, unique historical collections from the University archives, and teaching tools. The Jefferson Digital Commons allows researchers and interested readers anywhere in the world to learn about and keep up to date with Jefferson scholarship. This article has been accepted for inclusion in Jefferson Journal of Psychiatry by an authorized administrator of the Jefferson Digital Commons. For more information, please contact: JeffersonDigitalCommons@jefferson.edu. 


\section{Introduction}

The issue of physician impairment, that is, decreased ability or quality of functioning due to intemperate use of drugs or alcohol, emotional or psychiatric dysfunction, has recently received attention $(1,5)$. Studies have indicated the risks physicians face of substance abuse problems $(6,7)$, marital discord(8,9), suicide(10,11), and psychiatric problems(12-14). Studies have also addressed the difficulties faced by medical students(15-20).

A group of medical students at the University of North Carolina came together to investigate the subject of medical student impairment. A survey was constructed in order to ascertain the sources of stress in medical school. The results were used to develop a second survey instrument that was distributed to all students in the medical school and is presently being analyzed. A portion of the results are presented in this paper because of their unique focus on interpersonal relationships as sources of stress.

\section{Method}

The Physicians' Health Task Force was the group of UNC medical students previously mentioned. The Task Force met frequently and through the process of "brainstorming" generated a lengthy, open-ended survey designed to delineate problems as well as potential solutions in the medical school experience. The survey was introduced as an effort to learn about students' views on "stress and stress management practices." students were asked to list "stressful influences... and how you cope with these." The present report concerns part of the questionnaire related to interpersonal interactions in three key types of relationships: student-student, student-resident, and studentfaculty. For each relationship the respondent was asked how the relationship's interactions contributed to or alleviated stress. Students created their own answers in writing and the responses were tabulated in an attempt to identify the most common items.

Providing such an open-ended opportunity for free ranging expression made analyzing the answers difficult. Responses were grouped together under a general heading when they were noticeably similar, however, this still left many idiosyncratic comments that could be grouped only under "o:her." Because more than one answer was welcomed, the percentages listed are not proportions of respondents, but indicated how often the item was mentioned. The results were ranked in order of frequency and are listed in Tables $I-V_{i}$.

Dr. Jones is a first year psychiatry resident. 
The survey was distributed to forty students from the first year class, forty students from the second year class, and twenty each from the third and fourth year classes. Of the students who responded twenty-nine were first year, thirty-three were second year, while there were nine third year students and six fourth year students. Several upper-class students commented that the time constraints of clinical rotations and the length of the survey discourages its completion.

\section{$\underline{\text { Results }}$}

The responses obtained indicate that competitive classmates who were arrogant, who were "know-it-alls," and who were unable to discuss anything other than their studies made notable contributions to stress. Residents who insulted their charges, who taught by belittling students, or who did not teach at all were found to be sources of stress. Similarly, faculty members who were not respectful of students, who embarrassed them in front of others, or who played "guessing games" with students were frequently listed.

Conversely, the quality of the interactions between a medical student and his or her colleagues held the capability of alleviating stress. The most common method of handling stress mentioned was using friends to reevaluate and moderate difficult experiences. Higher quality teaching and more contacts with residents and attendings in a social context were listed as ameliorating stress.

The large number of "not applicable" responses concerning the studentresident relationship reflects the minimal contact between students and residents in the first two years. The "not applicable" responses for the remaining questions presumably means that the relationships did not increase or decrease stress for those respondents.

\section{Discussion}

Earlier assessments of medical student stress found worries about academic performance, personal happiness and patient related issues to be common. The vast amount of material to be learned and fear of poor performance on tests were consistently ranked high as sources of stress $(15,18,19,20)$. Lack of leisure time $(15,18,19,20)$ and the need for more study time $(19,20)$ were also frequently mentioned. Other aspects of concern to students were lack of money(19), "Rites of Passage" (excessive scut work)(21), and feelings of dehumanization(15). The results discussed in the present paper emphasized personal interactions and their relationship to stress as opposed to academic, administrative, or personal problems.

In recent years, attention from many professions has been directed towards understanding stress and its relation to health and well-being. Defining stress is difficult; it may represent primarily negative qualities for some, while others point out that stress can be productive and is essential to learning. Ambiguity in use of the term complicates research on the issue. 
(1) How do student-student interactions contribute to stress?

1. Competive classmates

16 responses

238

2. Table conferences, case conferences

3. Talking about studies

108

4. Arrogant, know-it-alls

5. Exams

6. Not knowing other students Other

None

Totals

Not applicable

(2) How do student-student interactions alleviate stress?

1. Friends, socializing

2. Sharing problems

29 responses other

None

Totals

$\underline{\underline{59}}$

Not applicable

(3) How do student-resident interactions contribute to stress?

1. Insults, put-downs, rudeness

2. No teaching

3. No feedback

$\begin{array}{ll}9 & \text { responses } \\ 4 & \\ 2 & \end{array}$

4. Poor role definitions, conflicting role

expections

other

None

No answer

Totals 
(4) How do student-resident interactions alleviate stress?

1. Good teaching

2. Socializing

3. Friendliness other

None

Totals

Not applicable
9 responses 348

519 8

27 은

830 \%

27

$26 \quad 1008$

$40 / 66$

$60 \%$

Table V

(5) How do student-faculty interactions contribute to stress?

1. Grilling students, condescending attitudes, embarrassing students, rudeness

2. Case conferences, presentations

18 responses

9

248

128

3. Answering question w/question, trying to find out what students don't know, "guess what I'm thinking"

4. Asking question in lecture

5. Unclear expectations other

None

Totals

Not applicable

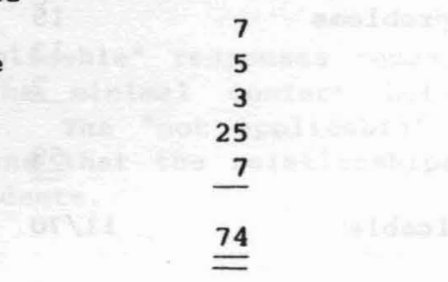

$15 / 89$
98

68

48

33 응

98

1008

168

Table VI

(6) What student-faculty interactions alleviate stress?

1. Informal learning opportunities

(available to talk, lab

interaction, low key rounds)

2. Socializing

3. Teaching (feedback, good answers)

4. Expression of concern, interest

5. Friendliness (sensitivity, humor) other

\begin{tabular}{ll}
8 responses & 208 \\
7 & $18 \%$ \\
7 & 188 \\
5 & 138 \\
4 & 108 \\
8 & 258 \\
\hline
\end{tabular}

Totals

Not applicable 
In the present survey, although stress was not formally defined as a positive or negative quality, it was referred to in a manner that recognized its deleterious aspects. The instructions asking how students "manage" and "coped with" their stresses cast the concept in a negative light. A later question on the survey was preceded with the statement, "We rsalize that stress is an important part of learning, but would like to identify unnecessary, unproductive areas of stress." Thus, for the purposes of the present survey, stress was referred to as a deterrent to a productive medical education, and the author assumes that those responding answered similarly.

Does stress necessarily detract from medical student education or always cause medical student impairment? This is a comment that reflects the sentiments of many administrators and medical students who feel that the stresses of medical education generate an impetus to learn. This again is evidence of the dichotomous nature of stress--it has both creative and destructive potential. If it is assumed that the responses to this susrvey represent the students' ideas of nonproductive stress, can it be shown that the students are correct in their perceptions? Perhaps those aspects of interpersonal relationships which students find stressful actually enhance learning rather than inhibit it. While a cause and effect relationship would be difficult to prove, examining the responses is helpful. Do competitive, arrogant classmates who talk only about their medical studies contribute to better medical education? Do insults, rudeness, and poor teaching on the parts of residents and attendings inspire students? It seems most unlikely that this is the case, although admittedly the present data do not statistically prove this to be so.

It is ironic that in a profession where successful competition has been a necessity for admission into the field, it is that same quality that is often listed as stressful. Rather than thrive on interpersonal competition, the results suggest that many students are dismayed (or worse) by fellow classmates who emphasize "winning the game" of medicine at the expense of their peers. One interpretation of the findings is that students tolerate the competitive aggressiveness that is encountered in medical training, but they do not relish these qualities, or admire those superiors who possess such attributes.

It is not surprising that socializing and sharing problems with friends is helpful, but it is important to mention since in previous studies(15,18) loneliness was listed as a major complaint. The life style of medicine not only selects, but develops individuals who tend to be self-reliant, responsible and thereby isolated from a full social life by lack of free time. Thus, a simple straightforward resource for coping is missing from some students' lives. Requests for less demanding hours or more free time may be ridiculed as evidence of lack of dedication, yet providing such opportunites or restructuring medical training to make them more available might ultimately improve the quality of education for medical students and care given to patients $(22,23,24)$.

Better teaching in any academic program is certainly always favored by its students, but the nature of clinical training in medical school makes it important to emphasize this point. Those charged with instructing students 
on the management of medical problems often have few guidelines to follow and little time to formally teach students. Medical students are usually under the direction of an intern, who may be burdened with greater demands than ever before in his or her career and who is thus rendered incapable of offering extended teaching $(25,26)$. Students also work with resident physicians, who may have more time, but who may or may not have the skills or the inclination to teach students. The teaching thus provided is often erratic in quality and quantity. The maxim, "See one, do one, teach one," may be adequate for venipuncture or other physical procedures, but formulating a differential diagnosis and treatment plan is not so easily replicated. Recognizing the desire of students to be taught and providing organized teaching of high quality are in the interests of students, faculty, and patients.

Students are interested not only in learning the science of diagnosis and treatment, they are looking for role models from whom they may acquire the art of medicine. It is essential to recognize the role that faculty and residents play in formulating the identity of the student as a compassionate, sensitive physician. To the extent educators can demonstrate such qualities, students will benefit. The extent that abusive, cynical attitudes dominate the faculty-student interactions, medical students and patients will suffer. 
REFERENCES

1. Tokarz JP: Beyond Survival. Chicago, American Medical Association, 1979.

2. Robertson J: The Impaired Physician: Building Well Being. Chicago, American Medical Association, 1980.

3. McCue J: The effects of stress on physicians and their medical practice. New England J Med 306:458-463, 1982.

4. Pfifferling JH: The Impaired Physician: An Overview. Chapel Hill, Health Sciences Consortium, 1980.

5. Povar GJ, Belz M: Helping ourselves. J Med Ed 55:632-634, 1980.

6. Thomas RB, Luber SA, Smith JA: A survey of drug and alcohol use in medical students. Diseases of the Nervous System $38(1): 41-43,1977$.

7. Vaillant GE, Brighton JR, McArthur C: Physicians' use of mood altering drugs. New England J Med 282:365-370, 1970 .

8. Thomas Св: What becomes of medical students: the dark side. Johns Hopkins Medical J 138:185-195, 1976.

9. Cameron $J$ : Significant problems revealed in impaired resident study . AAFP Reporter 5:1, 1978.

10. Ross, M: Suicide among physicians. Psychiatry in Medicine 2:189-198, 1971 .

11. Blachly PH, Osterud HT, Dossler R: Suicide in professional groups. New England J Med 268:1278-1282, 1963.

12. Schreiber SC: Emotional problems of physicians: I: nature and extent of problems. Arizona Medicine 34:323-325, 1977.

13. Valko RJ, Clayton PJ: Depression in the internship. Diseases of the Nervous System 36:26-29, 1975.

14. Watterson DJ: Psychiatric illness in the medical profession: incidence in relation to sex and field of practice. Canadian Med Assn J 115:311$317,1976$.

15. Edwards MT, Zimet CN: Problems and concerns among medical students-1975. J Med Ed 51:619-625, 1976.

16. Rosenberg P: Students' perceptions and concerns during their first year in medical school. J Med Ed 46:211-218, 1971. 
17. Cobern D, Jovaisas A: Perceived sources of stress among first-year medical students. J Med Ed 50:589-595, 1975.

18. Gottheil E, et al: stress, satisfaction and performance: transition from university to medical college. J Med Ed 44:270-277, 1969.

19. Miller GD, et al: Medical student needs assessmenst and student affairs programming. J Med Ed 56:518-520, 1981.

20. Boyle BP, Coombs RH: Personality profiles related to emotional stress in the initial year of medical training. J Med Ed 46:882-888, 1971 .

21. Huebner LA, et al: The assessment of remediation of dysfunctional stress in medical school. J Med Ed 56:547-558, 1981.

22. Cadden JE, et al: Growth in medical students through group process. Am J Psychiatry 126:862-868, 1969.

23. Dashef Ss, et al: Time-limited sensitivity groups for medical students. Am J Psychiatry 131:287-292, 1974 .

24. Siegel B, Donnelly JC: Enriching personal and professional development: the experience of a support group for interns. J Med Ed 53:908-914, 1978 .

25. Friedman RC, et al: Psychological problems associated with sleep deprivation in interns. J Med Ed 48:436-441, 1973.

26. Friedman RC, et al: The intern and sleep loss. New England J Med 285: 201-203, 1971 . 